\title{
Deformacje osadów kenozoicznych w zachodniej ścianie odkrywki Koźmin KWB ,Adamów"
}

\author{
Deformations of Cenozoic sediments in the western face of Koźmin outcrop KWB „Adamów”
}

\author{
Bartosz Stępień \\ Wydział Nauk Geograficznych, Uniwersytet Łódzki; stepienbart@gmail.com
}

Zarys treści: Deformacje osadów kenozoicznych w odsłonięciu w Koźminie znajdują się pomiędzy drugim poziomem nadkładu a poziomem eksploatacyjnym. Wśród zaburzeń wyróżniono mezostruktury o wielkości od kilkunastu do kilku metrów oraz drobne struktury deformacyjne o rozmiarach od kilku do kilkudziesięciu centymetrów. Pomiary strukturalne zostały zestawione w formie sferycznych diagramów wraz z rekonstrukcją kierunku lokalnego nacisku lądolodu. Analiza lokalnych pól naprężeń w oparciu o pomiary orientacji i wergencji struktur deformacyjnych pozwoliła wyznaczyć kierunki głównego nacisku (transportu glacitektonicznego) skierowanego z NNE-NE ku SSW-SW w przedziale azymutów 5-42 ${ }^{\circ}$. Analizowane struktury deformacyjne związane są z nasunięciem lądolodu zlodowacenia odry.

Słowa kluczowe: glacitektonika, analiza strukturalno-litofacjalna, centralna Polska

Abstract: Deformations of Cenozoic sediments in Koźmin exposure are situated between the second level of overlayer and a brown coal bench. In registered disturbances mesostructures in size from several to couple meters and fine structures in size from few to several dozen centimetres. The structural analysis was compiled in the spherical diagrams with the reconstruction of local ice flow. The examination of local stress poles on the basis of orientations and vergences measurements allowed to evaluate the main stress directions (glaciotectonic transport) from NNE-NE to SSW-SW (5-42 ${ }^{\circ}$ azimuth). Deformation structures are connected with ice-sheet of Odranian Glaciation.

Key words: glaciotectonics, structural and lithofacies analysis, central Poland

\section{Wprowadzenie}

Deformacje glacitektoniczne w Koźminie występują w obrębie słabo skonsolidowanych utworów neogenu i czwartorzędu. Obejmują one zdeformowane w bardzo różnym stopniu osady kilku jednostek litostratygraficznych: piaski, mułki, iły węgliste i iły pstre miocenu górnego, utwory czwartorzędowe reprezentowane przez żwiry, różnofrakcyjne piaski, mułki oraz glinę lodowcową zlodowacenia południowopolskiego. Miejscami w zaburzeniach bierze udział węgiel brunatny I-ego środkowopolskiego pokładu węglowego formacji poznańskiej.

W artykule przedstawiono wyniki badań deformacji glacitektonicznych widocznych w zachodniej ścianie nadkładu węgla brunatnego w odkrywce Koźmin (pole N). Badania terenowe prowadzone były w latach 20082009 w ramach gromadzenia materiałów do pracy magisterskiej. Celem badań było określenie typu oraz genezy deformacji osadów występujących w zachodniej ścianie odkrywki Koźmin KWB „Adamów”. Zgromadzone informacje pozwoliły także na sklasyfikowanie analizowanych struktur oraz dały możliwość wypowiedzenia się o rekonstrukcji lokalnego kierunku nacisku lądolodu. Wiek poszczególnych utworów został przyjęty na podstawie dokumentacji bilansu złoża „Koźmin” wg różnych autorów, a także z prac zwierających informacje o budowie geologicznej rowu Adamowa i obszarów sąsiednich. 


\section{Metody badań}

W odsłonięciu w Koźminie prowadzono badania litofacjalne osadów oraz analizę strukturalną deformacji glacitektonicznych. Badania litofacjalne polegały na rozpoznaniu cech struktur sedymentacyjnych i postsedymentacyjnych. W opisie osadów posłużono się kodem litofacjalnym wg Mialla (1977) i Rusta (1978) zmodyfikowanym przez Zielińskiego (1995).

Podstawową metodą badań struktur glacitektonicznych była analiza mezostrukturalna bazująca na określeniu typu i skali struktur, pomiarach ich orientacji oraz wergencji, a także określeniu osi fałdów na podstawie położenia warstw w skrzydłach. Analiza lokalnych pół naprężeń w oparciu o pomiar struktur glacitektonicznych pozwoliła wyznaczyć rzeczywiste kierunki głównego nacisku - transportu glacitektonicznego (Jaroszewski 1980, Roman 2010).

Struktury deformacyjne ze względu na ich skalę sklasyfikowano w dwie grupy. Wyróżniono kilku-, kilkudziesięciu metrowe mezostruktury reprezentowane przez większe uskoki odwrócone, fałdy, nasunięcia oraz drobne struktury deformacyjne o rozmiarach od kilku do kilkunastu centymetrów, które w analizowanych odsłonięciach występują w postaci zespołu uskoków normalnych, niewielkich uskoków odwróconych, brekcji glacitekto-

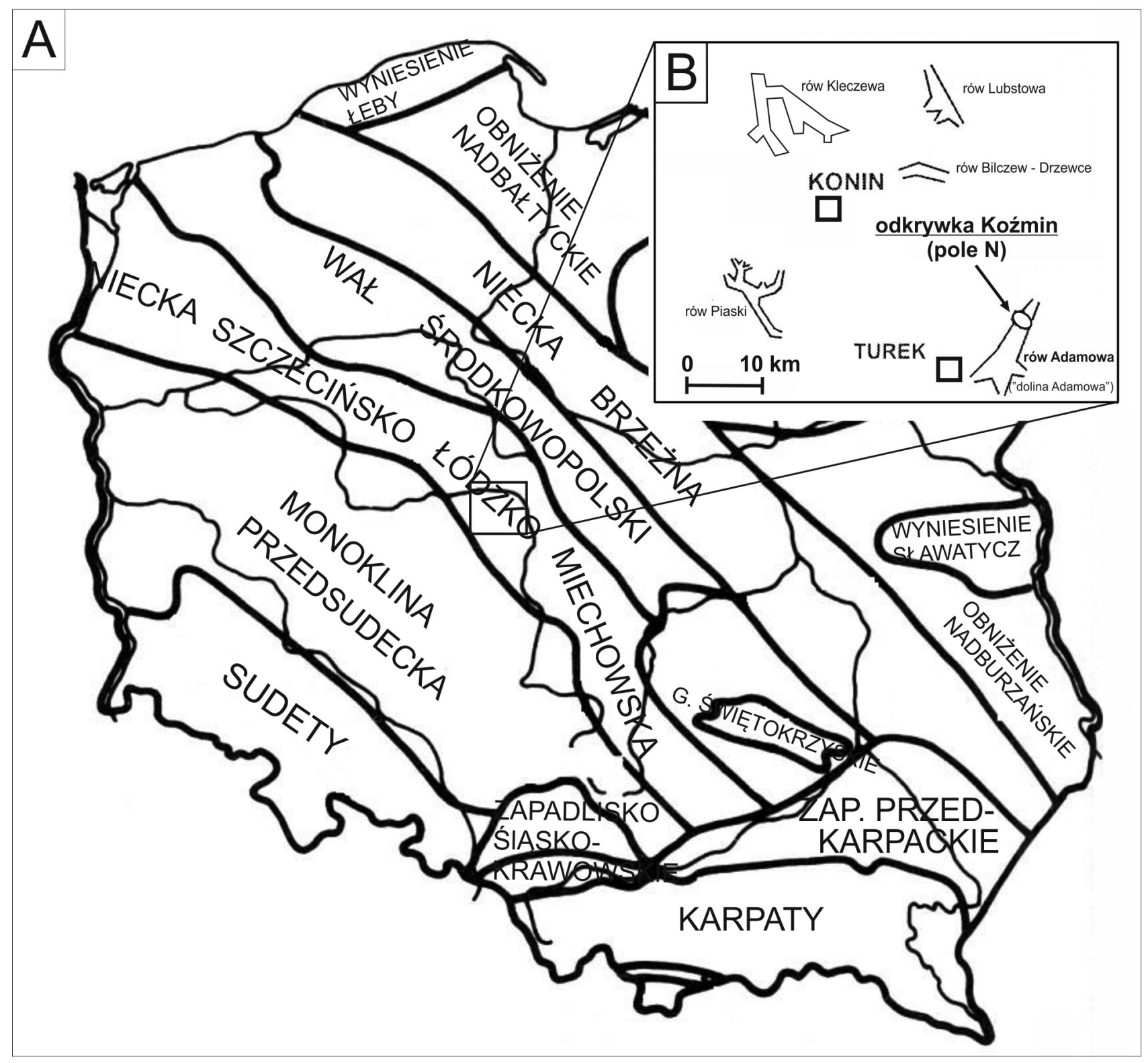

Ryc. 1. Położenie odkrywki Koźmin KWB „Adamów”

A - na tle głównych jednostek tektonicznych Polski wg Pożarskiego (1986), B - lokalizacja rowów tektonicznych w rejonie Konina wg Widery, Kity (2007)

Fig. 1. The localization of Koźmin outcrop KWB „Adamów”

A - background of Polish main tectonic units by Pożarski (1986), B - localization of tectonic grabens in the Konin regions by Widera, Kita (2007) 






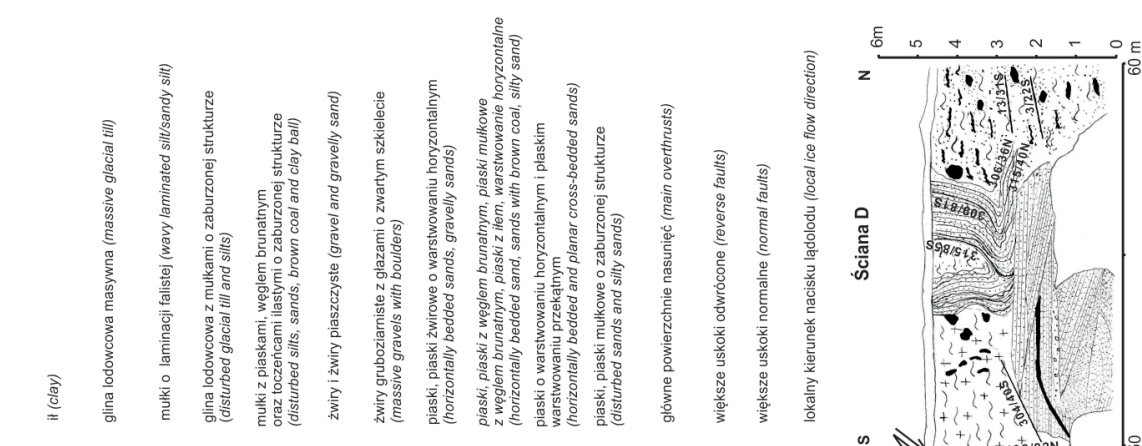

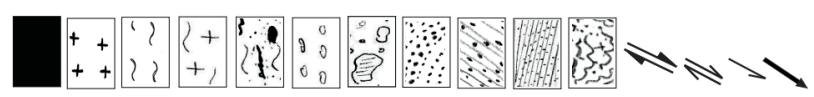
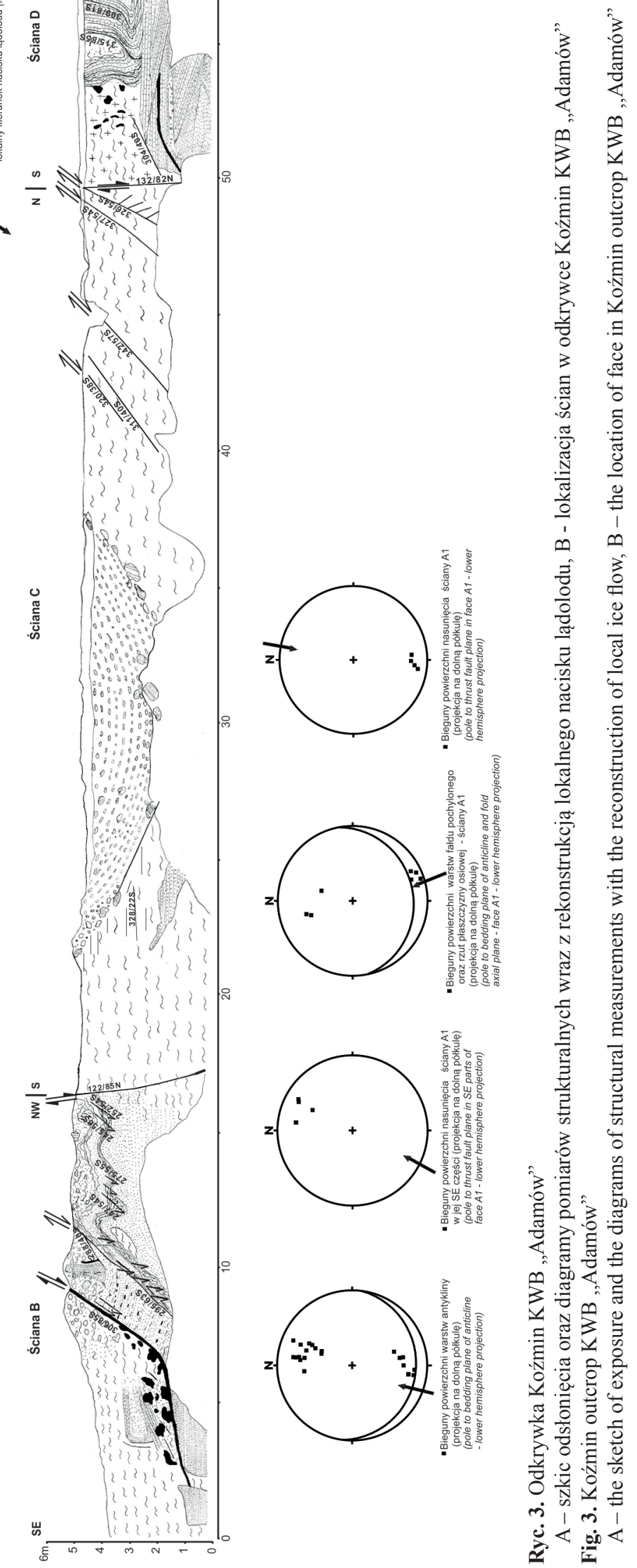
nicznej (Rotnicki 1971), drobnych fałdów ciągnionych, dysharmonijnych fałdków z płynięcia oraz kliważu spękaniowego (Jaroszewski 1980).

Dane strukturalne przedstawiono na diagramach punktowych, wykonanych w programie StereoNet $3.0-$ projekcja na dolną półkulę. Na siatce Wulffa wyznaczono konstrukcyjnie niektóre elementy geometrii struktur (np. osi fałdów na podstawie położenia warstw w skrzydłach). Sporządzony został szkic odsłonięcia w odkrywce Koźmin pole N, na którym zaznaczono: mapkę lokalizacyjną ścian w odkrywce, typy litologiczne osadów, wartości biegów i upadów, główne powierzchnie nasunięć, większe uskoki odwrócone i normalne oraz diagramy pomiarów strukturalnych wraz z rekonstrukcją kierunku lokalnego nacisku lądolodu. Przeprowadzono również dokumentację fotograficzną ścian i poszczególnych struktur.

\section{Sytuacja geologiczna stanowiska}

Kompleks deformacji glacitektonicznych wykształcony jest w obrębie osadów kenozoicznych, które reprezentowane są przez utwory miocenu środkowego do osadów wieku zlodowacenia odry. Analizowane zaburzenia występują w północnej strefie rowu Adamowa, jednego z rowów tektonicznych elewacji konińskiej położonej w środkowej części niecki mogileńsko-łódzkiej (ryc. 1), która od strony północno-wschodniej przylega do antyklinorium środkowopolskiego. Strukturę tę budują głownie osady cechsztyńsko-mezozoiczne o miąższości dochodzącej nieraz do $7 \mathrm{~km}$. Według Skoczylasa i Stankowskiego (1985) czynnikiem decydującym o charakterze i stylu budowy kompleksu cechsztyńsko-mezozoicznego były pionowe ruchy podłoża cechsztynu, które w istotny sposób wpłynęły na zmianę tempa i rodzaj sedymentacji oraz co ważne dla budowy osadów kenozoiku, mechanicznej deformacji nadległego kompleksu skalnego.

Obniżenie w podłożu mezozoicznym, w którym znajduje się odkrywka Koźmin nazywane było przez Czarnika (1972) „doliną Adamowa” (ryc. 1). Autor ten wiązał powstanie owej formy $\mathrm{z}$ erozją rzeczną $\mathrm{w}$ paleogenie. Natomiast Trzmiel (1996), Widera (1998) dysponując dużą ilością danych wiertniczych, a także danymi z postępującej eksploatacji w odkrywkach węgla brunatnego uważają, iż obniżenie to jest genezy tektonicznej. Widera łączy powstanie rowu Adamowa z intensywną aktywnością struktur solnych w czasie fazy laramijskiej.

Rów Adamowa ma szerokość 2-3 km, a długość jego wynosi $13 \mathrm{~km}$ (rozciąga się od E Turku do E Brudzewa). Zorientowany jest z kierunku SW do NE, a deniwelacje pomiędzy jego dnem w części osiowej a obszarami ramowymi wynoszą od 40-55 m. Najgłębsze miejsce rowu Widera (1998) wskazuje pod złożem Koźmin i określa je na poziomie 24,1 m n.p.m. Orientacja oraz przestrzenny zasięg rowu nie wykazuje bezpośredniego związku z strukturami głębszego podłoża, to znaczy z osiami struktur solnych oraz strefami uskoków rozdzielających sekwencję skał mezozoicznych.
Subsydencja w obrębie rowu Adamowa zachodziła intensywnie w trakcie sedymentacji węgla brunatnego i iłów formacji poznańskiej, w okresie od miocenu środkowego do górnego. W miocenie środkowym subsydencja podyktowana była głównie tektoniką, natomiast w górnym mogła być uwarunkowana kompakcją węgli brunatnych. Osady plejstocenu wykazują miejscami zmiany miąższości, które wskazywałyby na subsydencje rowu Adamowa w tym okresie (ryc. 2). Potwierdzać to mogą przykłady pionowych przemieszczeń osadów miocenu i plejstocenu w obrębie sąsiednich rowów i zrębów elewacji Konińskiej (Widera 1998, Stankowski 2000). Czwartorzęd w odkrywce Koźmin (pole N) reprezentowany jest przez trzy pokłady gliny lodowcowej, kilku kompleksów piaszczystych i piaszczysto-żwirowych. Średnia miąższość utworów czwartorzędowych w odkrywce wynosi około $30 \mathrm{~m}$ (Czubla i in. 2013).

\section{Opis odsłonięć}

Deformacje osadów kenozoicznych w odkrywce Koźmin znajdują się pomiędzy drugim poziomem nadkładu a poziomem eksploatacyjnym węgla brunatnego w jej zachodniej części. Struktury deformacyjne zarejestrowano w czterech ścianach, kolejno: A, B, C, D (ryc. 3). Dodatkowo istniała możliwość obserwacji i pomiarów struktur występujących w ścianie A od strony wschodniej (A1), gdyż ściana ta została rozcięta drogą dojazdową do złoża węgla brunatnego. Łączna długość odsłonięcia wynosi 83 m (wliczając ścianę A1 oraz A2). Największą długość posiada ściana $\mathrm{C}$, wynoszącą około $33 \mathrm{~m}$, natomiast ściana A2 ma tylko $8 \mathrm{~m}$ długości. Wysokości ścian odsłonięcia są dość zróżnicowane, zaledwie 2,5 m w środkowej części ściany C, $3 \mathrm{~m}$ w ścianie A2 aż do 7,5 m w NW części ściany A1.

\section{Ściana A1 i A2}

W ścianie A1 występuje dysharmonijna struktura antyklinalna (ryc. 3, ryc. 4A). Jej południowe skrzydło wykształcone jest głównie w postaci warstw masywnego diamiktonu o szarej barwie $(\mathrm{Dmm})$ oraz piasków drobnoziarnistych o laminacji horyzontalnej $(S h)$ z przewarstwieniami pył węglowego, a także piasków ze żwirami o warstwowaniu poziomym $(S G h)$. Warstwy tej struktury biegną niemal równoleżnikowo, natomiast ich upad jest dosyć zróżnicowany, zawarty w przedziale 36-74. W ścianie tej obserwuje się fałd pochylony (o amplitudzie około $3 \mathrm{~m}$ ) o wyraźnie ostrym przegubie oraz dość płaskich skrzydłach (fałd zygzakowaty - koncentryczny) (ryc. 4A). W strukturę tą zaangażowane są piaski drobnoziarniste oraz piaski mułkowe o warstwowaniu horyzontalnym (Sh, SFh), które ograniczone są od południa oraz północy pakietami gliny. Opisywany fałd ma wergencję północną. Na N skrzydło fałdu składają się piaski średnioziarniste $\mathrm{z}$ wkładkami węgla brunatnego $(S h)$, które poprzedzielane są cienkimi (do 1,0 cm) pakietami gliny 

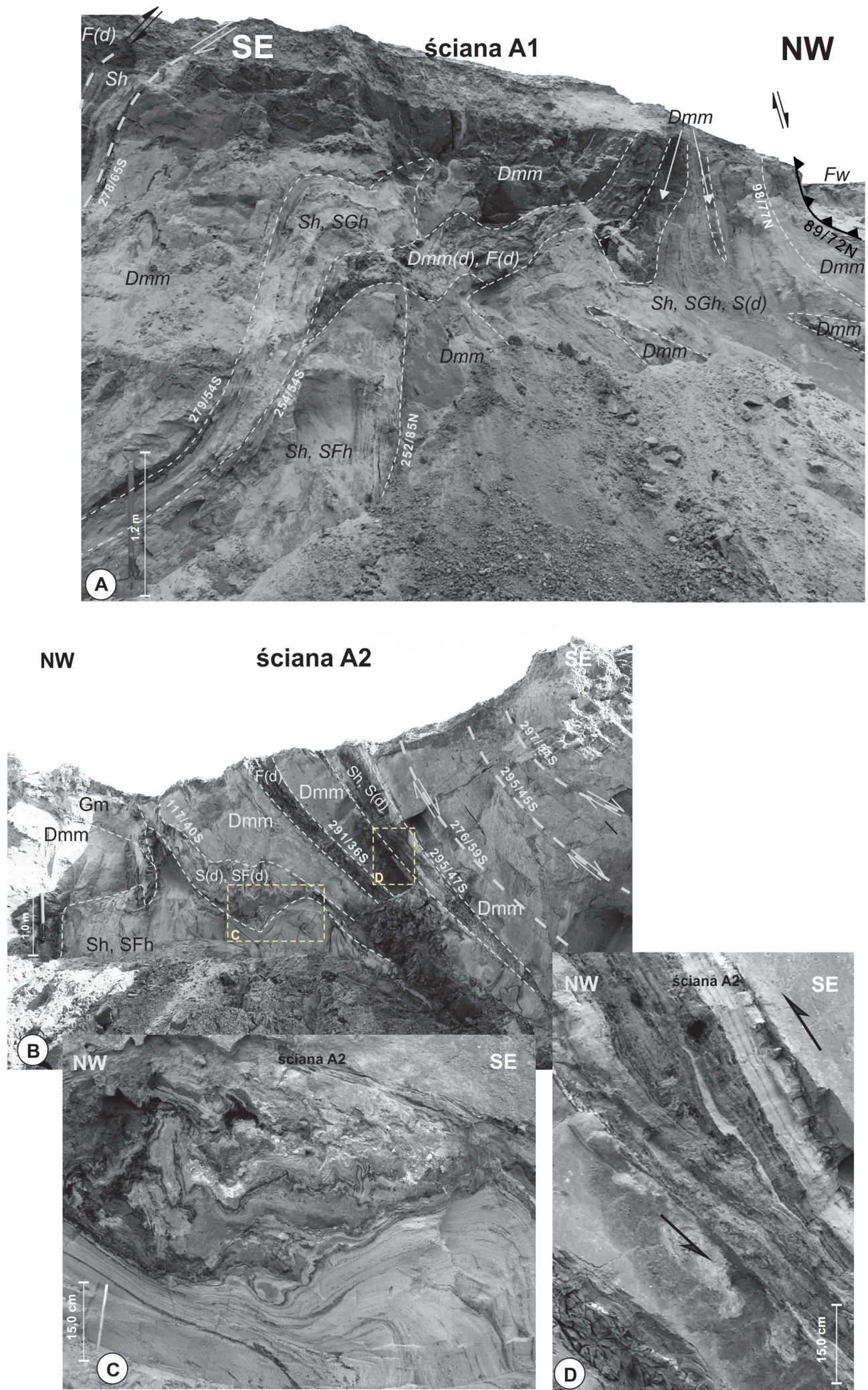

Ryc. 4. Struktury deformacyjne w zachodniej ścianie odkrywki Koźmin KWB „Adamów”

A - dysharmonijna struktura fałdowa i fałd pochylony o wyraźnie ostrym przegubie i dość płaskim skrzydle (fałd zygzakowaty koncentryczny) - ściana A1, B - wyraźnie widoczne warstwy S skrzydła antykliny - ściana A2, C - fałdki z turbulentnego płynięcia , D - fałdki z ciągnięcia rozwinięte w piaskach między dwoma pakietami gliny i kliważ spękaniowy wykształcony w ile pstrym pomiędzy pakietami gliny

Fig. 4. Deformation structures in the western face of Koźmin outcrop KWB „Adamów”

A - disharmonic fold and inclined fold with distinct sharp hinge and plane limb (chevron - concentric fold), B - well defined strata in $\mathrm{S}$ limb of anticline, $\mathrm{C}$ - rheid folds, $\mathrm{D}$ - drag folds formed between two deformed till packages and fracture cleavage developed in clay between two deformed till packages 
lodowcowej. Bieg warstw w N skrzydle fałdu posiada wartości $85-99^{\circ}$, natomiast upad wynosi od $58^{\circ}$ do $77^{\circ}$. Jądro dysharmonijnej struktury odsłoniętej w ścianie A1 wykształcone jest głównie laminowanych piasków i piasków mułkowych(Sh, SFh), często przewarstwionych piaskami grubymi z licznymi, wkładkami węgla brunatnego, w które wciśnięte są dwa nieregularne pakiety gliny lodowcowej. Wergencja warstw piaszczystych jądra jest skierowana $\mathrm{w}$ kierunku północnym, dlatego też można stwierdzić, iż osady te są tymi samymi piaskami, które wchodzą w skład warstw północnego skrzydła fałdu pochylonego. Struktura dysharmonijna występująca w ścianie A1 jest ograniczona od dwóch stron (SE i NW) powierzchniami nieciągłości (nasunięciami). W części SE ściany zaobserwowano bardzo wyraźną powierzchnię uskoku odwróconego rozdzielająca opisywaną antyklinę od silnie spękanych i zaburzonych mułków $(F(d))$. Bieg tej powierzchni jest bliski równoleżnikowemu, natomiast ogólne jej nachylenie jest w kierunku S. W części NW analizowanej ściany występuje druga powierzchnia nasunięcia, oddzielająca strukturę antyklinalną od nasunięcia zbudowanego z mułków $(F w)$. Opisywana powierzchnia zapada się na N pod kątem $67-77^{\circ}$, natomiast jej bieg jest także niemal równoleżnikowy. Powierzchnia tego nasunięcia jest „wysmarowana” górnomioceńskim, iłem węglistym, który w wielu miejscach wciska się w spękania gliny lodowcowej, tworzącej warstwy N skrzydła struktury dysharmonijnej. Ze względu na małą powierzchnię odsłonięcia ściany A2, struktura antyklinalna jest widoczna w niewielkim stopniu (ryc. 4B). Dobrze rozpoznawalne są warstwy S skrzydła antykliny, a także piaszczyste osady jej jądra . Strukturą, która nie występowała w ścianie A1 jest niewielki fałd pochylony (w części NW ściany), którego warstwy S skrzydła biegną prawie równoleżnikowo, natomiast zapadają pod kątem $67-75^{\circ}$. Fałd ten otoczony jest żwirem masywnym o rozproszonym i zwartym szkielecie ziarnowym ( $\mathrm{Gm}, \mathrm{Gcm})$ z licznymi głazami dochodzącymi do 0,35 m średnicy. Żwiry te w ścianie A1 (od strony wschodniej) nie zostały zaobserwowane.

Drobne deformacje zarejestrowane $\mathrm{w}$ ścianie A2 to fałdki z płynięcia turbulentnego (ang. rheid folds) (Jaroszewski 1980, Brodzikowski 1982). Występują one w strefie kontaktu osadów piaszczystych jądra (głównie w piaskach drobnoziarnistych oraz mułkowych $(S(d)$, $S F(d)$ ), a także w silnie zaburzonych mułkach $(F(d))$ z niewielkimi warstewkami gliny lodowcowej. W tym przypadku osadami bardziej podatnymi w procesie fałdowania były mułki oraz piaski mułkowe tworzące liczne dysharmonijne fałdki z płynięcia (ryc. 4C). Drugą grupę drobnych struktur tworzą fałdki ciągnione (ang. drag folds) (ryc. 4D), które wg Jaroszewskiego (1980) powstają w utworach cechujących się dużą zmiennością litologiczną pomiędzy poszczególnymi pakietami. W Koźminie fałdki ciągnione wykształciły się w piaskach drobnoziarnistych przewarstwionych pyłem węglowym o warstwowaniu poziomym $(S h)$. Obejmują warstwy podatniejsze na zginanie niż górna i dolna warstwa gliny lodowcowej. Fałdki te odznaczają się dużą asymetrycznością, a ich powierzchnie osiowe są zazwyczaj pochylone w stronę przegubu antykliny -powierzchnie osiowe posiadają wergencję północną (Krysiak 2007). Kolejną strukturą o niewielkich rozmiarach jest kliważ spękaniowy (Jaroszewski 1980) (ryc. 4D), który rozwinął się w warstwie względnie bardziej podatnego na boczne ściskanie iłu pstrego niż otaczających go warstw gliny lodowcowej. Występuje on tylko $\mathrm{w}$ warstwie iłu, natomiast zanika na granicy $\mathrm{z}$ warstwą niepodatną. Powierzchnie kliważu spękaniowego są podobnie jak w przypadku powierzchni osiowych fałdków ciągnionych pochylone w stronę przegubu struktury antyklinalnej (Jaroszewski 1980).

\section{Ściana B}

W odsłonięciu ściany B, o długości 17 m, można zaobserwować dysharmonijny fałd antyklinalny (ryc. 3, ryc. 5A). Warstwy S skrzydła antykliny wykształcone są w zaburzonych piaskach mułkowych $(S F(d))$ oraz drobnoziarnistych i średnioziarnistych piaskach z licznymi wkładkami materiału organicznego $(S(d))$. W dolnej części opisywanego skrzydła, między warstwami piasków mułkowych i mułków widoczny jest ił pstry. Warstwy struktury antyklinalnej biegną niemal równoleżnikowo, natomiast skrzydło zapada się na S pod kątem 58-63 (ryc. 3). Na SE od S skrzydła antykliny znajduje się dość duży uskok odwrócony (uskok ławicowy), który powstał na odkuciu wzdłuż powierzchni międzyławicowej, oddzielając tym samym osady piaszczyste występujące w synklinie (ryc. 3). Warstwy struktury synklinalnej zostały ścięte od SSE przez powierzchnię uskokową. Powierzchnia ślizgu powleczona jest na całej powierzchni iłem pstrym. Powierzchnia ta posiada bieg $295-304^{\circ}$, natomiast upada w kierunku S pod kątem $74-84^{\circ}$. W ścianie tej zaobserwowana została bardzo interesująca struktura w postaci niewielkiego fałdu powstałego w strefie ślizgu, najprawdopodobniej w czasie rozwoju dysharmonijnej struktury fałdowej. W fałd ten zaangażowane są głownie osady piaszczyste, w postaci piasków drobnoziarnistych i mułkowych, przewarstwionych piaskami z pyłem węglowym oraz mułkiem. Utwory piaszczyste z licznymi przewarstwieniami mułków tworzą bardzo skomplikowane deformacje w strefie grzbietowej antykliny. W odsłonięciu tym nie występują osady N skrzydła antykliny, gdyż najprawdopodobniej zostały ścięte przez nasuniecie mułków widoczne w NW części opisywanej ściany. Osadami przykrywającymi dysharmonijną strukturę fałdową ściany B są słabo wysortowane, masywne żwiry o zwartym szkielecie ziarnowym $(\mathrm{Gcm}) \mathrm{z}$ licznymi głazami o średnicy od 0,15 do $0,25 \mathrm{~m}$.

Wśród zaburzeń o niewielkiej skali warte odnotowania są powszechnie występujące w S skrzydle antykliny fałdki z płynięcia turbulentnego (ryc. 5B, 5C), którym towarzyszą fałdki z laminarnego płynięcia (Brodzikowski 1982). Lokalnie przepływ doprowadził do uformowania struktur budinażopodobnych. Deformacje te rozwinęły się w drobnoziarnistych i mułkowych piaskach licznie przewarstwionych mułkami oraz iłem, piaskach grubych 

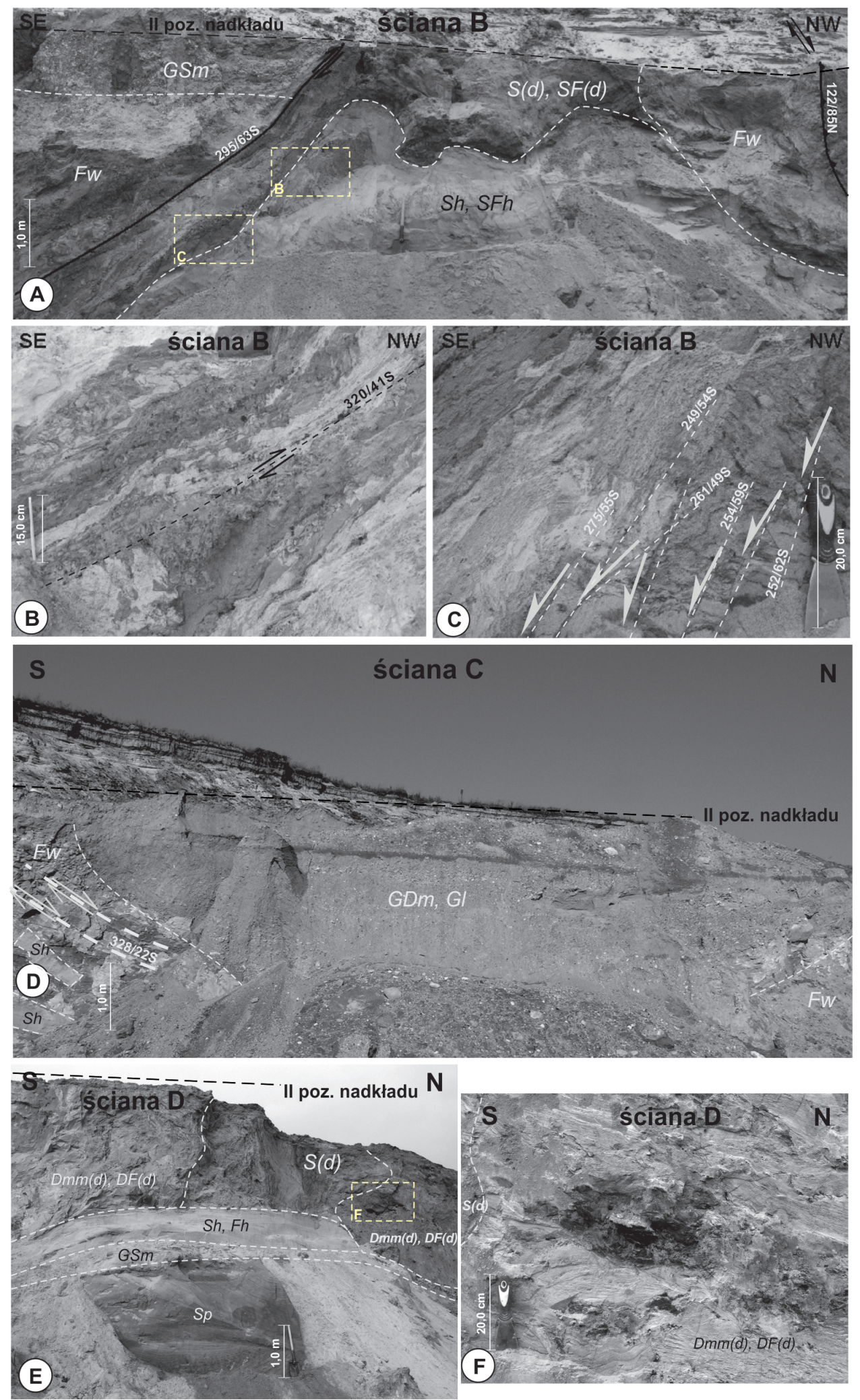

Ryc. 5. Struktury deformacyjne w zachodniej ścianie odkrywki Koźmin KWB „Adamów”

A - dysharmonijna struktura antyklinalna, B - w S skrzydle antykliny widoczne są fałdki z turbulentnego płynięcia, którym towarzyszą fałdki z laminarnego płynięcia, C - drobne struktury z płynięcia poprzecinane niewielkimi uskokami normalnymi zapadającymi ku S, D - wielkoskalowe rozmycie kanałowe występujące w ścianie C, E - silnie zaburzone osady czwartorzędowe i mioceńskie, $\mathrm{F}$ - fragment węgla brunatnego otoczonego iłem węglistym pogrążony w zaburzonych piaskach i mułkach czwartorzędowych

Fig. 5. Deformation structures in the western face of Koźmin outcrop KWB „Adamów”

A - disharmonic anticline structure, B - in S limb of anticline visible rheid folds accompanied with laminar flow folds, C - fine deformation structures crossed by fine normal faults collapsed through S, D - large-scale washout channel, E - strongly disturbed Quaternary and Miocene sediments, F - fragment of brown coal surrounded by clay deepened in deformed Quaternary sands and silts 
z cienkimi wkładkami węgla brunatnego. Analizowane mikrostruktury $\mathrm{S}$ skrzydła antykliny poprzecinane są stromymi uskokami normalnymi, które zapadają ku S (ryc. 5C). Podobne struktury $\mathrm{z}$ płynięcia turbulentnego rozwinęły się w strefie grzbietowej antykliny. Obserwuje się tutaj także zespół stromych uskoków normalnych, które wygasają w utworach piaszczystych $(S h, S F h)$ budujących trzon struktury antyklinalnej. Płaszczyzny uskoków mają biegi $245-275^{\circ}$ i zapadają w kierunku $\mathrm{S}$ pod kątem 54-72 ${ }^{\circ}$. W sąsiedztwie uskoków normalnych zarejestrowano także pojedynczy uskok ławicowy, którego powierzchnia uskokowa (276/37 S) wykształciła się w ławicy iłu węglistego.

W NW części ściany, na kontakcie zaburzonych piasków dysharmonijnej struktury fałdowej $\mathrm{z}$ nasunięciem mułków, zachodziło intensywne wciskanie piasku w szczeliny spękanego mułku, co w rezultacie doprowadziło do powstania brekcji glacitektonicznej (Rotnicki 1971, 1976), która wg Brodzikowskiego (1982) powstaje najczęściej w strefach kontaktu nasunięć lub łusek glacitektonicznych. Struktura fałdowa widoczna w ścianie B jest ograniczona od NW powierzchnią nasunięcia biegnącą z WNW-ESE (118-123ํ) zapadającą ku N pod kątem $67-85^{\circ}$ (ryc. 3). W dolnej części ściany B , tak daleko jak było to możliwe, odsłonięto fragment powierzchni nasunięcia z wyraźnie widocznym lustrem tektonicznym pokrytym górnomioceńskim iłem węglistym.

\section{Ściana C}

Deformacje zarejestrowane w ścianie C są w głównej mierze reprezentowane przez mezostrukturę w postaci jednego i wyraźnego nasunięcia, które widoczne jest w odsłonięciu na długości $35 \mathrm{~m}$. Strukturę tą budują głównie czwartorzędowe mułki o laminacji falistej $(F w)$ z przewarstwieniami materiału ilastego (wiek mułków ustalony na podstawie profili wiertniczych pochodzących z dokumentacji geologicznej bilansowania złoża „Koźmin”). W S części ściany C, w dolnej partii odsłonięcia, w obrębie mułków dostrzegalne są dwa niezaburzone pakiety horyzontalnie warstwowanych piasków (Sh). Najprawdopodobniej materiał ten został zagarnięty z podłoża podczas tworzenia się opisywanego nasunięcia. W środkowej części ściany występuje wielkoskalowe rozmycie kanałowe wypełnione masywnym żwirem gruboziarnistym i głazami diamiktonowymi $(G D m)$ (ryc. 5D). W wyższych partiach kanał zbudowany jest z żwirów gruboziarnistych o zwartym i rozproszonym szkielecie o warstwowaniu równoległym do dna kanału $(G l)$. W dnie rozmycia zaobserwować można był głazy dochodzące do 0,6 m średnicy.

W N części analizowanej ściany występuje zespół dość dużych, równoległych uskoków odwróconych, których powierzchnie ślizgu najprawdopodobniej rozwinęły się na granicach sedymentacyjnych mułków. Uskoki te zapadają na południe pod kątem $38-57^{\circ}$, natomiast ich bieg zawarty jest w przedziale $314-342^{\circ}$. Zaobserwowano, iż tylko dwa $\mathrm{z}$ pięciu uskoków wygasają $\mathrm{w}$ odsłonięciu.

\section{Ściana D}

W analizowanym odsłonięciu Koźmin, na granicy ściany C i D, występuje kolejna powierzchnia nasunięcia, która oddziela nasunięcie ściany $\mathrm{C}$ od struktur deformacyjnych ściany D (ryc. 3, ryc. 5E). Biegnie ona w kierunku NW$\mathrm{SE}$. Na kontakcie $\mathrm{z}$ mezostrukturą ściany $\mathrm{C}$ znajduje się bardzo silnie zaburzona glina lodowcowa, miejscami wymieszana $\mathrm{z}$ mułkami oraz fragmentami węgla brunatnego otoczonego iłem węglistym $(\operatorname{Dmm}(d), D F(d))$. W centralnej części odsłonięcia widoczna jest niewielka struktura fałdowa w postaci fałdu przewalonego wykształconego w drobnoziarnistych i mułkowych piaskach o zaburzonej strukturze $(S(d))$. Charakterystyczną cechą tego fałdu jest to, iż warstwy skrzydła grzbietowego zapadają pod bardzo dużym kątem $81-97^{\circ}$, natomiast warstwy skrzydła brzusznego są nachylone pod kątem $18-32^{\circ}$. Bezpośrednio pod tą strukturą znajduje się kompleks szarych piasków drobnoziarnistych i iłów laminowanych poziomo $(S h, F h)$. Pod nim w sposób nieciągły leży pakiet drobnoziarnistych piasków z przewarstwieniami pyłu węglowego o płaskim warstwowaniu przekątnym $(S p)$. Między pakietami odsłania się wąska warstwa masywnego żwiru piaszczystego o zwartym szkielecie ziarnowym $(\mathrm{DSm})$. W dolnych partiach $\mathrm{N}$ części ściany zaobserwować można wyraźny kontakt osadów piaszczystych z silnie zaburzonym kompleksem składającym się z gliny lodowcowej, miejscami wymieszana z mułkami $(\operatorname{Dmm}(d), D F(d))$, ilastymi toczeńcami uzbrojonymi o średnicy do $1 \mathrm{~cm}$, a także większymi kawałkami węgla brunatnego otoczonego iłem węglistym (ryc. 5F). Opisywane osady poprzecinane są niewielkimi uskokami normalnymi (powierzchnie uskoków dochodzą do $15 \mathrm{~cm}$ długości). Kompleks ten widoczny jest po zachodniej stronie aż do północnej ściany odkrywki Koźmin.

\section{Geneza struktur deformacyjnych}

Analiza lokalnych pól naprężeń w oparciu o pomiary orientacji i wergencji mezostruktur deformacyjnych pozwoliła wyznaczyć kierunki głównych nacisków, które skierowane są prostopadle do powierzchni nasunięć, powierzchni uskoków odwróconych czy też płaszczyzn osiowych struktur fałdowych. Otrzymane wyniki świadczą, że powstanie deformacji kenozoicznych w Koźminie należy wiązać z działaniem kompresji subhoryzontalnej $\left(S_{H}\right)$. Zbieżność kierunków głównych nacisków (transportu glacitektonicznego) odczytanego z analizy mezostruktur kompresyjnych z wergencją struktur drobnych wskazuje, iż czynnikiem zaburzającym był ten sam, jeden lądolód zlodowacenia odry (Czubla i in. 2013).

Warstwy antykliny występujące w ścianie A1 posiadają wyraźny związek z powierzchniami ślizgu występujących zarówno w SE jak i NW części ściany. Uwidacznia się to w podobnym usytuowaniu powierzchni uskokowej występującej w SE części ściany z biegiem płaszczyzny osiowej antykliny. Kierunek oraz kąt zapadania warstw 
S skrzydła antykliny położonych w blisko powierzchni uskoku odwróconego jest bardzo zbliżony. Podobna sytuacja występuje w części NW ściany A1. Północne warstwy opisywanej struktury antyklinalnej, wykształcone z piasków oraz pakietów gliny, posiadają zbliżone biegi $\mathrm{z}$ orientacją powierzchni nasunięcia. Kierunek kompresji subhoryzontalnej, identyfikowany z lokalnym kierunkiem nacisku lądolodu, określony na podstawie położenia powierzchni uskokowej oraz płaszczyzny osiowej struktury antyklinalnej, a także orientacji S warstw tej struktury skierowany jest z NNE ku SSW (Krysiak 2007, Roman 2007). W przypadku wykształcenia struktur w NW części ściany A1 największy lokalny nacisk pochodził także z kierunku NNE do SSW. Struktura antyklinalna powstałaby zatem podczas procesu kompresji subhoryzontalnej poprzez spiętrzanie i wyciskanie osadów, budujących obecnie warstwy antykliny, na przedpolu czoła nasunięcia. Dysharmonijne jądro opisywanej struktury jest natomiast rezultatem odmiennej reakcji osadów, poprzez różne właściwości fizyczne glin, mułków oraz piasków, na wytrzymałość na odkształcenie oraz ścinanie (Rotnicki 1971). Południowa wergencja powierzchni osiowej struktury antyklinalnej oraz niewielkiego fałdu pochylonego znajdującego się w środkowej części ściany dowodzi, iż kompresja miała miejsce z kierunku N-NNE. Zdaniem autora powierzchnię uskokową widoczną w SE części ściany A1 oraz B można uznać za powierzchnie uskoku przeciwstawnego (drugiego rzędu) o nachyleniu skierowanym w przeciwną stronę niż dyslokacja główna. Taki uskok mógł się rozwinąć w strefie kontaktu odkucia lub innego nasunięcia (nie widocznego w analizowanym odsłonięciu), wypieranego z kierunku NNE ku SSW, z progiem skał mezozoicznych. Świadczyć może o tym strop margli górnokredowych (na wysokości 72 m n.p.m.) znacznie wyżej położony niż na obszarach położonych w kierunku N (ryc. 2). W odsłonięciu ściany B widoczna jest podobna sytuacja jaką zaobserwowano w ścianie A1. Tutaj dysharmonijna struktura fałdowa także ograniczona jest $\mathrm{z}$ dwóch stron powierzchniami uskokowymi. Orientacja warstw S skrzydła antykliny oraz powierzchni uskoku odwróconego nawiązuje do biegu powierzchni nasunięcia w SE części ściany. Wyznaczony kierunek skierowany jest z NNE ku SSW. Kolejna powierzchnia nasunięcia występująca w NW części ściany wyraźnie ścina N skrzydło antyklinalnej struktury fałdowej. Kompresja wywołana lokalnym naciskiem lądolodu w tym przypadku zwrócona była także z kierunku NNE ku SSW. Powyższe dane pozwoliły stwierdzić, iż dysharmonijna struktura fałdowa zaobserwowana w ścianie B jest kontynuacją struktury antyklinalnej ściany A1 i A2, gdyż warstwy w skrzydłach jednej jak i drugiej struktury biegną niemal równoleżnikowo. Pakiet szarych mułków występujący w SE części ściany A1 oraz B najprawdopodobniej stanowi jedną część większej struktury, która z uwagi na ograniczoną powierzchnię odsłonięcia oraz dość duże rozmiary wymyka się możliwości dokładniejszego zbadania. Natomiast fragment nasunięcia widoczny w NW części ściany A1 jest częścią nasunięcia zaobserwowanego w ścianie
C, ponieważ orientacja powierzchni ślizgu nasunięcia W ścianie A1 jest bardzo zbliżona do biegu powierzchni nasunięcia zarejestrowanej w ścianie $\mathrm{C}$.

Zespoły uskoków normalnych występujące w S skrzydle dysharmonijnej struktury fałdowej w ścianie B powstały w wyniku procesów wczesnodiagenetycznych, zachodzących w danym ośrodku skalnym od chwili zakończenia jego deformacji do konsolidacji. Układ naprężeń, który charakterystyczny jest dla tego typu deformacji to działanie pary sił w płaszczyźnie pionowej przy grawitacyjnej orientacji osi działania naprężenia głównego $\left(S_{V}\right)$. Dlatego też struktury te mogły powstać podczas deglacjacji lądolodu na tym obszarze. Odmienną genezę posiadają uskoki normalne zarejestrowane w strefie przegubowej struktury fałdowej. W procesie powstawania fałdów na drodze kompresji horyzontalnej często w zewnętrznych partiach antykliny rozwijają się lokalne naprężenia rozciągające, które prowadzą do powstawania spękań ekstensywnych (przegubowych) mogących przerodzić się, jak to prawdopodobnie miało miejsce w obrębie antykliny , w wyraźny zespół stromych uskoków normalnych (Jaroszewski 1980).

Dość skomplikowaną genezę posiadają struktury widoczne w ścianie D odsłonięcia w Koźminie. Powierzchnia ślizgu rozdzielająca nasunięcie ściany $\mathrm{C}$ od nasunięcia osadów ściany D biegnie w kierunku NW-SE (125-132º. Zatem kierunek kompresji poziomej, prostopadły do biegu powierzchni ślizgowej, zawarty jest w przedziale azymutów 35-42 ${ }^{\circ}$, czyli skierowany z NE ku SW. Nasunięcie to można byłoby uznać za łuskę glacitektoniczną z uwagi na to, iż podobne osady ciągną się przynajmniej kilkadziesiąt metrów na północ, praktycznie aż do północnej ściany odkrywki Koźmin (ta część odsłonięcia nie była przedmiotem badań autora $\mathrm{w}$ ramach niniejszej pracy).

Bardzo ważnym zagadnieniem, które musi być brane pod uwagę przy próbie określenia genezy struktur deformacyjnych w obszarze występowania rowów tektonicznych jest wpływ procesów endogenicznych, które mogły uaktywnić się podczas kolejnych zlodowaceń (Brodzikowski 1985, Liszkowski 1993, Aber, Ber 2007). Wiadomo za Brodzikowskim (1982, 1985, 1987), Liszkowskim (1993) i Aberem, Berem (2007), iż na obszarach objętych zlodowaceniem przy równoczesnej subsydencji, która może być uruchomiona na danym obszarze przez obciążenia lądolodem, wpływ mechanicznego oddziaływania lodu na podłoże jest redukowany, w przypadku gdy kierunek ruchu utworów podlegających obniżaniu jest zbliżony do lokalnego nacisku wywieranego przez lądolód. Zatem osady znajdujące się na obszarach, gdzie zachodzi subsydencja posiadają większą odporność na siły wywołujące deformacje, a także większą zdolność do przenoszenia naprężeń wywołanych obecnością lądolodu. Dlatego też, deformacje glacitektoniczne w takich strukturach geologicznych charakteryzują się niewielkimi rozmiarami zaburzeń (Brodzikowski 1985, Czubla, Załoba 1995). Według Brodzikowskiego (1985) te prawidłowości powinny być najmocniej brane pod uwagę przy charakterystyce deformacji pochodzenia glacjalnego na obszarach, gdzie 
występowały pionowe ruchy skorupy ziemskiej częściowo wywołane obciążeniem lądolodu.

Drugim ważnym elementem jest paleorzeźba jaką napotkał lądolód na obszarze rowu tektonicznego. W przypadku rowu Adamowa mamy do czynienia z brakiem opracowań, które mogłyby dostarczyć istotnych danych o tym zagadnieniu. Ogólnie wiadomym jest, iż wszelkie elewacje skał starszych lub w przypadku rowów tektonicznych dość wysoko położone skrzydło wiszące stanowiące przeszkodę na drodze poruszającego się lądolodu jest strefą powstawania oraz nagromadzenia deformacji glacitektonicznych (Jaroszewski 1991, Aber, Ber 2007). Bariery na drodze transgredującego lądolodu mogą także stymulować wzrost gradientu naprężeń subglacjalnych. Według Brodzikowskiego (1982, 1985, 1987) struktury deformacyjne pochodzenia glacitektonicznego występujące w obniżeniach o założeniu tektonicznym rozwijają się najczęściej w środowisku subglacjalnym, jak przytaczane przez tego autora deformacje z odkrywki Bełchatów utworzone w strefie rowu Kleszczowa.

\section{Podsumowanie}

W oparciu o analizę strukturalną deformacji glacitektonicznych wyznaczono kierunku lokalnego nacisku (transportu glacitektonicznego), który utożsamiany jest z kierunkiem ruchu lądolodu. Otrzymane wyniki pozwoliły ustalić, że główny kierunek kompresji subhoryzontalnej jest skierowany z NNE-NE ku SSW-SW lub w przedziale azymutów $5-42^{\circ}$. Wyniki badań z odsłonięcia w Koźminie potwierdzają wcześniejsze badania Czubli i Załoby (1995), którzy opisywali deformacje fałdowe w klifie zbiornika Jeziorsko w Siedlądkowie i stwierdzili, iż główne naciski przyczyniające się do powstania owych struktur deformacyjnych pochodziły z kierunku NNE oraz NNW. Znając orientację rowu Adamowa, z kierunku SW do NE, można sądzić, iż poruszający się lądolód na tym obszarze najprawdopodobniej wykorzystywał niewielkie obniżenie terenu, które mogło powstać w wyniku uaktywnienia subsydencji podłoża związane z obciążeniem lądolodem. Nagłe impulsy sejsmiczne, które prowadzą do gwałtownego obniżania lub wynoszenia podłoża rowów, mogły powodować istotną zmianę gradientu naprężeń, a to indukować lokalne zmiany kierunku głównych nacisków.

Nagromadzenie, w analizowanym odsłonięciu, struktur o charakterze kompresyjnym (nasunięcia, łuski, uskoki odwrócone, struktury fałdowe) utworzonych w warunkach subhoryzontalnej kompresji $\left(S_{H}\right)$ świadczy, iż najprawdopodobniej zaburzenia utworzone zostały pod wpływem nacisków dynamicznych przed czołem nasuwającego się lądolodu lub pod lądolodem w czasie jego aktywnego nasuwania się (w strefie proglacialnej). Nie można jednoznacznie zanegować wpływu czynników endogenicznych w procesie deformacji osadów (Brodzikowski 1982, 1985, Bruj, Krysiak 2009).

W odsłonięciu w Koźminie prowadzone były badania, które miały na celu określenie wieku zaburzonej gliny lodowcowej widocznej w ściana A1, A2, oraz D. Dzięki temu zaistniała możliwość wypowiedzenia się na temat wieku zaburzeń. Zaangażowanie zarejestrowanej gliny, która pochodzi z zlodowacenia san 2 (Czubla i in. 2013) oraz brak glin korelowanych z zlodowaceniem krzny a obecność niezaburzonego horyzontu gliny zlodowacenia odry może wskazywać, iż lądolód powodujący powstanie deformacji należy wiązać z zlodowaceniem odry. Znajduje to potwierdzenie $\mathrm{w}$ badaniach przeprowadzonych przez Włodarskiego (2009) w strefie rowu Kleczewa (północna część elewacji konińskiej), z których wynika, że kompleks deformacji glacitektonicznych wykształcony w obrębie osadów kenozoicznych, datowanych na miocen środkowy - zlodowacenie odry, utworzony został w czasie transgresji lądolodu zlodowacenia odry.

\section{Podziękowania}

Autor pragnie podziękować Pani Profesor Małgorzacie Roman za wnikliwą lekturę i pomocne uwagi w procesie przygotowywania artykułu.

\section{Literatura}

Aber J.S., Ber A., 2007. Glaciotectonism. Developments in Quaternary Science. Elsevier, Amsterdam 6: 1-246.

Brodzikowski K., 1982. Deformacje osadów nieskonsolidowanych w obszarach niżowych zlodowaceń plejstoceńskich na przykładzie Polski południowo-zachodniej. Acta Universitatis Wratislaviensis 574, Prace Geograficzne 34.

Brodzikowski K., 1985. Glacial deformation environment in the subsiding zone with special reference to the Kleszczów tectonic Graben. Quaternary Studies in Poland 6: 5-21.

Brodzikowski K., 1987. Środowiskowe podstawy analizy i interpretacji glacitektonizmu Europy Środkowej. Acta Universitatis Wratislaviensis 934, Studia Geograficzne 43.

Bruj M., Krysiak Z., 2009. Struktury glacitektoniczne w osadach plejstoceńskich kopalni węgla brunatnego Bełchatów. Prace Państwowego Instytutu Geologicznego 194: 7-26.

Czarnik J., 1972. Paleogeografia okolic Turka w górnym trzeciorzędzie i plejstocenie. Studia Geologica Polonica 40.

Czubla P., Załoba M., 1995. Examples of deformation structures in deposits of different ages in the vinicity of the Uniejów Basin and the eastern part of the Turek Plateau. Acta Geographica Lodziensia 68: 198-210.

Czubla P., Forysiak J., Petera-Zganiacz J., Grajoszek M., Wiśniewska M., 2013. Charakterystyka litologiczno-petrograficzna osadów czwartorzędowych w dolinie Warty (stanowisko Koźmin-Północ). Przegląd Geologiczny 61: 120-126.

Jaroszewski W., 1980. Tektonika uskoków i fałdów. Wydawnictwo Geologiczne, Warszawa.

Jaroszewski W., 1991. Rozważania geologiczno-strukturalne nad genezą deformacji glacitektonicznych. Annales de la Societe Geologique Polonaise 61: 153-206.

Krysiak Z., 2007. Analiza drobnych struktur glacitektonicznych i jej przydatność w rekonstrukcji kierunków ruchu lądolodu. Biuletyn Państwowego Instytutu Geologicznego 425: 35-46.

Liszkowski J., 1993. The effects of Pleistocene ice-sheet loading-deloading cycles on the bedrock structure of Poland. Folia Quaternaria 64: 5-23.

Miall A. D., 1977. A review of the braided river depositional environment. Earth-Science Reviews 13: 1-62.

Roman M., 2007. Morena spiętrzona z transgresji lądolodu stadiału głównego zlodowacenia wisły w Paruszewicach na Pojezierzu Kujawskim. W: P. Molewski, W. Wysota, P. Weckwerth (red.), Plejstocen 
Kujaw i dynamika lobu Wisły ostatniego zlodowacenia. Państwowy Instytut Geologiczny, Warszawa: 209-217.

Roman M., 2010. Rekonstrukcja lobu płockiego w czasie ostatniego zlodowacenia. Acta Geographica Lodziensia 96.

Rotnicki K., 1971. Struktura deformacji w strefie wtórnego kontaktu łusek glacitektonicznych w Winiarach koło Kalisza. Badania Fizjograficzne nad Polską Zachodnią 24: 199-236.

Rotnicki K., 1976. Glacitektoniczna struktura poziomego nasunięcia łusek. Badania Fizjograficzne nad Polską Zachodnią 29: 103-123.

Rust B.R., 1978. Depositional models for braided alluvium. W: A.D.Miall (red.), Fluvial Sedimentology. Canadian Society of Petroleum Geologists. Memoir 5: 605-625.

Skoczylas J., Stankowski W., 1985. Wpływ procesów geologicznych na charakter rzeźby okolic Konina. Badania Fizjograficzne nad Polską Zachodnią 35: 173-190.

Stankowski W., 2000. Kenozoik okolic Konina. Wycieczka A. Geologia i ochrona środowiska Wielkopolski. Przewodnik 71 Zjazdu Polskiego Towarzystwa Geologicznego: 97-102.
Trzmiel B., 1996. Objaśnienia do szczegółowej Mapy Geologicznej Polski 1: 50 000, ark. Turek (550). Państwowy Instytut Geologiczny, Warszawa.

Widera M., 1998. Ewolucja paleomorfologiczna i paleotektoniczna elewacji konińskiej. Geologos 3: 55-103.

Widera M., Kita A., 2007. Paleogene marginal marine sedimentation In central - western Poland. Geological Quarterly 51: 79-90.

Włodarski W., 2009. Analiza strukturalno-kinetyczna kompleksu deformacji glacitektonicznych w strefie rowu Kleczewa (elewacja konińska, wschodnia Polska). Prace Państwowego Instytutu Geologicznego 194: 75-100.

Zieliński T., 1995. Kod litofacjalny i litogenetyczny - konstrukcja i zastosowanie. W: E. Miecielska-Dowgiało, J. Rutkowski (red.), Badania osadów czwartorzędowych. Wybrane metody i interpretacja wyników. Wydział Geografii I Studiów Regionalnych Uniwersytetu Warszawskiego, Warszawa: 220-235. 